\title{
TRANSACTIONS of the
}

\section{AMERICAN FISHERIES SOCIETY}

Volume 116

September 1987

Number 5

Transactions of the American Fisheries Saciety 116:677-691, 1987

(C) Copyright by the American Fisheries Society 1987

\section{Diet and Selection of Major Prey Species by Lake Michigan Salmonines, 1973-1982}

\author{
David J. Jude, Frank J. Tesar, Scott F. Deboe, and Timothy J. Miller \\ Great Lakes Research Division, University of Michigan \\ Ann Arbor, Michigan 48109, USA
}

\begin{abstract}
To elucidate prey preferences, we quantified stomach contents of 1,231 salmonines collected from inshore ( $21 \mathrm{~m}$ or shallower) southeastern Lake Michigan during 1973-1982. Predators ate 12 species of fish. Alewife Alosa pseudoharengus made up $48-79 \%$ by weight of the diet of brown trout Salmo trutta, chinook salmon Oncorhynchus tshawytscha, coho salmon Oncorhynchus kisutch, lake trout Salvelinus namaycush, and rainbow trout Salmo gairdneri. Alewives eaten ranged from 23 to $245 \mathrm{~mm}$ total length; $46 \%$ were $150-200 \mathrm{~mm}$. Rainbow smelt Osmerus mordax eaten were 21-245 mm long and made up 4-11\% of the salmonines' prey. There were significant direct linear relationships between lengths of alewives and rainbow smelt eaten and lengths of the five predators. Alewives are currently declining in Lake Michigan. If their population collapses, there should be a shift to alternative prey species. We have seen no such shift through 1982, although more recent data of other investigators show a decline in the importance of alewife in salmonine diets. Diets of the midwater-feeding chinook and coho salmon were heavily dominated by the pelagic alewife, whereas brown and lake trout diets were more diverse. This suggests that trout should have better survival and growth than salmon, because trout would be able to utilize the more benthic yellow perch, Perca flavescens, rainbow smelt, and, to some degree, bloater Coregonus hoyi. The latter species are becoming more abundant with the decline in alewife. Under the current salmonine stocking regime, alewives will continue to supply a lower and variable portion of the salmonine diet, and predatory pressure on alewife should lead to increases in endemic prey species' populations.
\end{abstract}

The present Great Lakes salmonine fishery is very important to sport fishermen. The five salmonine species that inhabit most of the Great Lakes, lake trout Salvelinus namaycush, rainbow trout Salmo gairdneri, brown trout Salmo trutta, coho salmon Oncorhynchus kisutch, and chinook salmon Oncorhynchus tshawytscha, are maintained largely by stocking in quantities unrelated to the abundances of prey on which they depend. The potential for predator-prey destabilization is great if stocks of alewife Alosa pseudoharengus, the major prey species, collapse (Jude and Tesar 1985), or if predators outstrip their food supply
(Stewart et al. 1981). Information on the diet of salmonines is important for successful management of the predator-prey system in the Great Lakes. In the case of Lake Michigan, such diet information can help in the monitoring of any substantial change in prey stocks or in predicting the way salmonines may respond to such a change (Stewart et al. 1981). Diet information, along with energetics models, can be used by fishery managers to help select the most appropriate predator to exploit available prey should the alewife population collapse.

During 1973-1982, the period that this paper 
addresses, the prey fish species sustaining the salmonines in Lake Michigan were mainly alewife and rainbow smelt Osmerus mordax and, occasionally, sculpins Cottus spp. From 1980 to 1982 , the alewife population declined $86 \%$ in southeastern Lake Michigan, while abundances of yellow perch Perca flavescens and rainbow smelt increased (Jude and Tesar 1985). Populations of yellow perch and, to some degree, rainbow smelt are believed to be depressed when alewives are abundant (Smith 1968). Starting in 1977, the population of bloaters Coregonus hoyi expanded (Jude and Tesar 1985), presumably as a result of both the 1976 closure of commercial fishing for this species in Lake Michigan and the decline of alewife. In light of these events, our objectives were to establish the composition of the diet of the five most important salmonines inhabiting Lake Michigan, to determine what size and species of prey they selected by season, and to relate what was eaten to the sizes and abundances of prey fish populations present in Lake Michigan. Our results did not indicate that a shift to other prey occurred in the face of the alewife decline from 1980 to 1982.

\section{Methods}

Field sampling. - Prey and predatory fish were collected from southeastern Lake Michigan at two sites, one 16 and the other $24 \mathrm{~km}$ south of the St. Joseph River mouth. Sand was the predominant bottom type in the area. Stations were established at water depths of $1,6,9$, and $21 \mathrm{~m}$.

Three gear types were deployed to collect prey and predator fish by day and night once a month from April to November 1973-1982. Seines were used at three $1-\mathrm{m}$ stations, and trawling and gillnetting were conducted at two 6- and two 9-m stations. Supplementary gillnetting and trawling were occasionally conducted separately at a 6-, a 9-, and a 21-m station. Fish were also seined and gillnetted during December and January-March on an irregular basis. The beach seine was $38 \times$ $1.8 \mathrm{~m}(6.35-\mathrm{mm}$ mesh) and was hauled twice in the same direction parallel to shore for nonoverlapping $61-\mathrm{m}$ stretches at each station. Gill nets were $160 \times 1.8 \mathrm{~m}$ with 12 bar-mesh sizes from 1.3 to $10.2 \mathrm{~cm}$ and were set for approximately 12 $\mathrm{h}$ during the day and $12 \mathrm{~h}$ at night. The trawl had a 4.9-m headrope and 1.9-cm-bar mesh, and was towed at a speed of $5 \mathrm{~km} / \mathrm{h}$. Tows were duplicated and were $10 \mathrm{~min}$ in duration. Most prey fish collected were frozen as soon as possible, whereas salmonines were usually processed within $4 \mathrm{~h}$ after removal from the nets. Fish less than $1 \mathrm{~kg}$ were weighed to the nearest $0.1 \mathrm{~g}$; larger fish were weighed to the nearest $25 \mathrm{~g}$. Fish were measured to the nearest millimeter total length (TL), and their sex was determined. Details on methods are described by Jude et al. (1979) and Jude and Tesar (1985).

Stomach processing. - Stomachs were removed from juvenile salmonines ( $<20 \mathrm{~cm}$ long) collected mostly with seines in 1973 and 1974, but no stomachs were examined quantitatively in 1975-1982. However, fish collected in later years had their stomachs opened and examined qualitatively as part of our routine fish processing. No dramatic changes in diet were noted from 1973-1974 observations. Because these fish ate insects almost exclusively, lack of quantitative data over the latter period of the study when alewife populations declined should not affect conclusions drawn about the diet of small salmonines in the near-shore zone. Stomachs were preserved in $10 \%$ formaldehyde solution. Stomach contents were later examined, and total volumes $\left(\mathrm{cm}^{3}\right)$ were determined volumetrically, then converted to grams on a one-toone basis. Percent composition of prey items eaten was estimated visually and was used to calculate the weight (g) contributed by each food group. Food items were grouped into four major categories: fish, invertebrates, fish eggs (mostly alewife), and plant materials (macrophytes and algae). The highest percentage that fish eggs and plant material contributed in any season or size group was $4.4 \%$ for rainbow trout.

Predators longer than $20 \mathrm{~cm}$ were examined in each study year. Individual prey were removed from stomachs, identified if possible, then weighed to the nearest $0.1 \mathrm{~g}$. Lengths (to nearest $\mathrm{mm}$ ) were recorded for whole prey fish and estimated for partially digested fish. Data from detailed analysis of fish less than $20 \mathrm{~cm}$ collected in 1973-1974 are pooled in the tables and figures with data from fish $30 \mathrm{~cm}$ or shorter collected in 1973-1982.

Data analysis. - For each predator species, food data were analyzed by percent weight composition and percent frequency of occurrence. Data were grouped for comparisons according to season (spring: March-May; summer: June-August; fall: September-November). Only 18 predators had eaten during winter so only brief summaries of these data are presented. Preliminary analysis of all data by predator-length interval showed a change in diet at about $30 \mathrm{~cm}$, so we combined data into "small fish" $(\leq 30 \mathrm{~cm})$ and "large fish" $(>30 \mathrm{~cm})$ categories. To examine changes in feed- 
ing activity of predators over seasons, we calculated the percentage of the total number of each size group captured with food present, and then used chi-square tests of independence to determine any significant differences. If differences were found, pairwise tests were performed to find differences among seasons.

Measures of food intake relative to fish size were determined by calculating an "index of fullness" (weight of stomach contents as a percentage of total body weight of each predator: Hyslop 1980). Index values were $\log _{10}$-transformed and subjected to analysis of variance performed to ascertain differences in feeding intensity among seasons. Only large lake trout, brown trout, and coho salmon provided sufficient sample sizes for this analysis. For each salmonine species, regression analysis was used to establish a relationship between length of predator and length of alewife and rainbow smelt prey (or average length if more than one was found in a stomach; this was done to maintain independence among samples). In addition, an analysis of covariance was performed (predator length was the covariate) to determine any significant differences in mean size of alewife prey among seasons for large lake trout, brown trout, and coho salmon (sample sizes were too small for chinook salmon and rainbow trout). If a significant difference was found, Scheffé pairwise comparisons were used to determine which seasons' mean lengths were significantly different. Mean numbers of alewife prey per stomach were also calculated for each season, and chi-square tests of independence were used to ascertain significant differences. We grouped data into four categories: stomachs containing one, two, three, and four or more alewives. Again, if a dependence was found across seasons, pairwise tests were performed. Similar tests were performed for data on rainbow smelt prey but data were pooled for all large salmonines because of the small sample size. For tests of seasonal dependence on number of prey per stomach, only three intervals $(1,2,3+)$ were used. To address selectivity and availability of prey fish, length frequencies were compared for alewife and rainbow smelt in predator stomachs (for all salmonines combined) and for those captured in field gear for each season (pooled over 10 years).

\section{Results}

During 1973-1982, we collected 4,894 salmonines, among which food was present in 1,065 large and 1,352 small fish; contents were quantified for $848(80 \%)$ and $365(27 \%)$, respectively
(Table 1). Fish were collected every month of the year, including winter, when 18 fish with food in their stomachs were taken (not in Table 1).

\section{Brown Trout}

Of 331 small brown trout stomachs examined, $71 \%$ contained food. Average lengths of those fish with food were similar among seasons $(P=0.717)$. A significantly lower proportion of small brown trout contained food in spring than in fall or summer $(P=0.003$; Table 1$)$. Fish made up the majority of the total weight of prey eaten for each season, averaging $90 \%$ in spring; invertebrates dominated remaining weights (Figures 1, 2). Alewives made up $7-37 \%$ of the diet over all three seasons. Rainbow smelt and spottail shiner were preyed on in summer and sculpins were prey in spring (Table 2; Figure 1). Fish eggs were eaten during all three seasons.

Of large brown trout, $56 \%$ contained food, the highest percentage of all large salmonines. This proportion was significantly lower in fall than in spring or summer (chi-square, $P=0.001$; Table 1). Indexes of fullness for each season were similar $(P=0.122$; Table 1). Fish accounted for almost $100 \%$ of the total weight of food eaten, and invertebrates (chironomid adults, crayfish, Gammarus sp., and snails) made up the remainder (Figures 1, 2).

Among identified fish eaten, alewives contributed approximately $78 \%$ of the total weight in spring and $90 \%$ in summer and fall (Figure 1). Most remaining fish prey were rainbow smelt, which decreased in importance from spring through fall. Some young-of-the-year bloaters were eaten in fall. In winter, seven large and two small brown trout ate gizzard shad and rainbow smelt. In spring, rainbow smelt were $13 \%$ of the total weight of brown trout diets; sculpins made up 5\% (Figure 1). Brown trout diets contained much higher proportions of sculpins, spottail shiner, bloater, and johnny darter than occurred in the diets of other salmonines (Table 2; Figure 2).

Average length of alewives consumed by large brown trout was significantly smaller in fall (61 $\mathrm{mm}$ ) because more young of the year were eaten then than in spring $(139 \mathrm{~mm})$ and summer $(P=$ 0.001 ; Table 3 ). In addition, the average number of 5.3 alewives per stomach was significantly higher $(P=0.02)$ in fall than in spring or summer.

\section{Chinook Salmon}

Of the small chinook salmon captured during spring and summer, 93-95\% had food in their 
TABLE 1.-Sample sizes and percentages of fish with food in stomachs for small and large salmonines caught in southeastern Lake Michigan, 1973-1982. Mean indexes of stomach fullness (\% of body weight) are given for large fish where sample sizes were adequate. Seasonal values for each species followed by the same letter are not significantly different (chi-square tests and analyses of variance; $P<0.05$ ).

\begin{tabular}{|c|c|c|c|c|c|c|c|c|c|}
\hline \multirow[b]{3}{*}{ Season } & \multicolumn{4}{|c|}{ Fish $\leq 30 \mathrm{~cm}$ total length } & \multicolumn{5}{|c|}{ Fish $>30 \mathrm{~cm}$ total length } \\
\hline & \multirow[b]{2}{*}{$N$} & \multirow[b]{2}{*}{$\begin{array}{l}\% \text { with } \\
\text { food }\end{array}$} & \multirow{2}{*}{$\begin{array}{l}\text { Stomachs } \\
\text { pro- } \\
\text { cessed }\end{array}$} & \multirow{2}{*}{$\begin{array}{l}\text { Mean weight } \\
\text { (g) of stomach } \\
\text { contents } \\
(\text { mean } \pm \mathrm{SD})^{\mathrm{a}}\end{array}$} & \multirow[b]{2}{*}{$N$} & \multirow[b]{2}{*}{$\begin{array}{l}\% \text { with } \\
\text { food }\end{array}$} & \multirow{2}{*}{$\begin{array}{l}\text { Stomachs } \\
\text { pro- } \\
\text { cessed }\end{array}$} & \multicolumn{2}{|c|}{$\begin{array}{l}\text { Stomach contents } \\
\quad(\text { mean } \pm \mathrm{SD})^{\mathrm{a}}\end{array}$} \\
\hline & & & & & & & & $\begin{array}{l}\text { Weight }(\mathrm{g}) \\
\text { per stomach }\end{array}$ & $\begin{array}{c}\% \text { of body } \\
\text { weight }\end{array}$ \\
\hline \multicolumn{10}{|c|}{ Brown trout } \\
\hline Spring & 139 & $62 \mathrm{z}$ & 25 & $2.0 \pm 3.8$ & 183 & $62 \mathrm{z}$ & 81 & $37.5 \pm 43.2$ & $1.8 \pm 1.6 \mathrm{z}$ \\
\hline Summer & 136 & $76 y$ & 52 & $1.8 \pm 2.8$ & 94 & $72 \mathrm{z}$ & 52 & $19.5 \pm 22.4$ & $1.2 \pm 1.1 \mathrm{z}$ \\
\hline Fall & 56 & $84 \mathrm{y}$ & 26 & $1.0 \pm 0.9$ & 152 & $38 \mathrm{y}$ & 27 & I7.2 \pm 22.1 & $1.4 \pm 1.6 \mathrm{z}$ \\
\hline \multicolumn{10}{|c|}{ Chinook salmon } \\
\hline Spring & 301 & $95 \mathrm{z}$ & 20 & $0.3 \pm 0.3$ & 168 & $14 \mathrm{z}$ & 15 & $45.1 \pm 57.8$ & \\
\hline Summer & 493 & $93 \mathrm{z}$ & 58 & $0.3 \pm 0.4$ & 25 & $56 y$ & 10 & $6.0 \pm 4.1$ & \\
\hline Fall & 98 & $67 y$ & 30 & $2.5 \pm 2.1$ & 52 & $17 \mathrm{z}$ & 5 & $12.7 \pm 9.0$ & \\
\hline \multicolumn{10}{|c|}{ Coho salmon } \\
\hline Spring & 85 & $92 \mathrm{z}$ & 25 & $0.5 \pm 0.4$ & 307 & $44 z$ & 119 & $17.1 \pm 16.6$ & $1.4 \pm 1.2 \mathrm{z}$ \\
\hline Summer & 44 & $61 y$ & 23 & $1.0 \pm 0.7$ & 67 & $87 y$ & 54 & $38.5 \pm 27.8$ & $2.0 \pm 1.2 \mathrm{y}$ \\
\hline Fall & 5 & 40 & I & 8.0 & 58 & $21 x$ & 9 & $9.9 \pm 7.9$ & \\
\hline \multicolumn{10}{|c|}{ Lake trout } \\
\hline Spring & 23 & $70 \mathrm{z}$ & 9 & $0.5 \pm 0.4$ & 278 & $73 \mathrm{z}$ & 172 & $51.3 \pm 43.8$ & $1.7 \pm 1.3 \mathrm{z}$ \\
\hline Summer & 30 & $70 \mathrm{z}$ & 12 & $0.9 \pm 0.6$ & 227 & $66 z$ & 143 & $29.0 \pm 24.8$ & $1.0 \pm 0.8 \mathrm{y}$ \\
\hline Fall & 10 & $80 \mathrm{z}$ & 5 & $3.2 \pm 3.5$ & 1,627 & $12 y$ & 148 & $23.7 \pm 19.4$ & $0.8 \pm 0.7 y$ \\
\hline \multicolumn{10}{|c|}{ Rainbow trout } \\
\hline Spring & 63 & $84 \mathrm{z}$ & 39 & $1.6 \pm 1.3$ & 32 & $12 \mathrm{z}$ & 5 & $12.6 \pm 11.5$ & \\
\hline Summer & 54 & $96 z$ & 23 & $2.0 \pm 1.6$ & 9 & $44 \mathrm{z}$ & 3 & $34.3 \pm 40.4$ & \\
\hline Fall & 46 & $83 \mathrm{z}$ & 17 & $3.5 \pm 4.7$ & 32 & $34 \mathrm{z}$ & 5 & $13.2 \pm 15.7$ & \\
\hline
\end{tabular}

a Stomachs with food only.

stomachs, but the percentage declined significantly to $67 \%$ in fall (Table 1). Diets were composed of fish and invertebrates (mostly chironomid adults and terrestrial insects) in spring and summer, whereas fish dominated in fall (Figure 1). The main reason for this (and for differences in percentage of fish stomachs containing food) is most likely that average predator length was much greater in fall than in spring or summer. Chinook salmon ate rainbow smelt and spottail shiner in spring and summer (Table 2). Chinook salmon that were eating fish in fall preyed most heavily upon alewives; rainbow smelt and trout-perch were also eaten.

Of all large salmonines, chinook salmon had the highest percentage of empty stomachs (79\%). Percentage of feeding fish was significantly higher in summer than in spring or fall, but mean weight per stomach was much lower in summer (Table 1). Stomach contents were exclusively fish (Figure 2); alewives and rainbow smelt were the only identified fish prey (Table 2). Rainbow smelt made up a greater proportion of the weight of identified fish prey in summer than spring. Alewives were the only identified fish prey found in fall. Alewife av- erage length $(138 \mathrm{~mm})$ and number per stomach were highest in spring (Table 3 ).

\section{Coho Salmon}

Eighty percent of all small coho salmon captured contained food. The percentage was significantly higher in spring than summer or fall $(P=$ 0.001 ), although sample size was small during fall (Table 1). The dominant food group in the diet during spring and summer was invertebrates (terrestrial insects and chironomid pupae), but fish contributed $40 \%$ by weight (Figure 1). Occurrence of fish prey in the diet increased from spring to summer (Table 2), as did average length of small coho salmon, which was significantly greater in summer than in other seasons $(P=0.001)$.

For the 10 -year period, $48 \%$ of the large coho salmon contained food. Significantly more fish were feeding in summer than in spring or fall seasons, and significantly more fed in spring than in fall $(P<0.001$; Table 1). Mean values for index of fullness were significantly higher in summer than in spring (Table 1). Alewives made up a large proportion of the diet in all seasons (Figure 1) and 


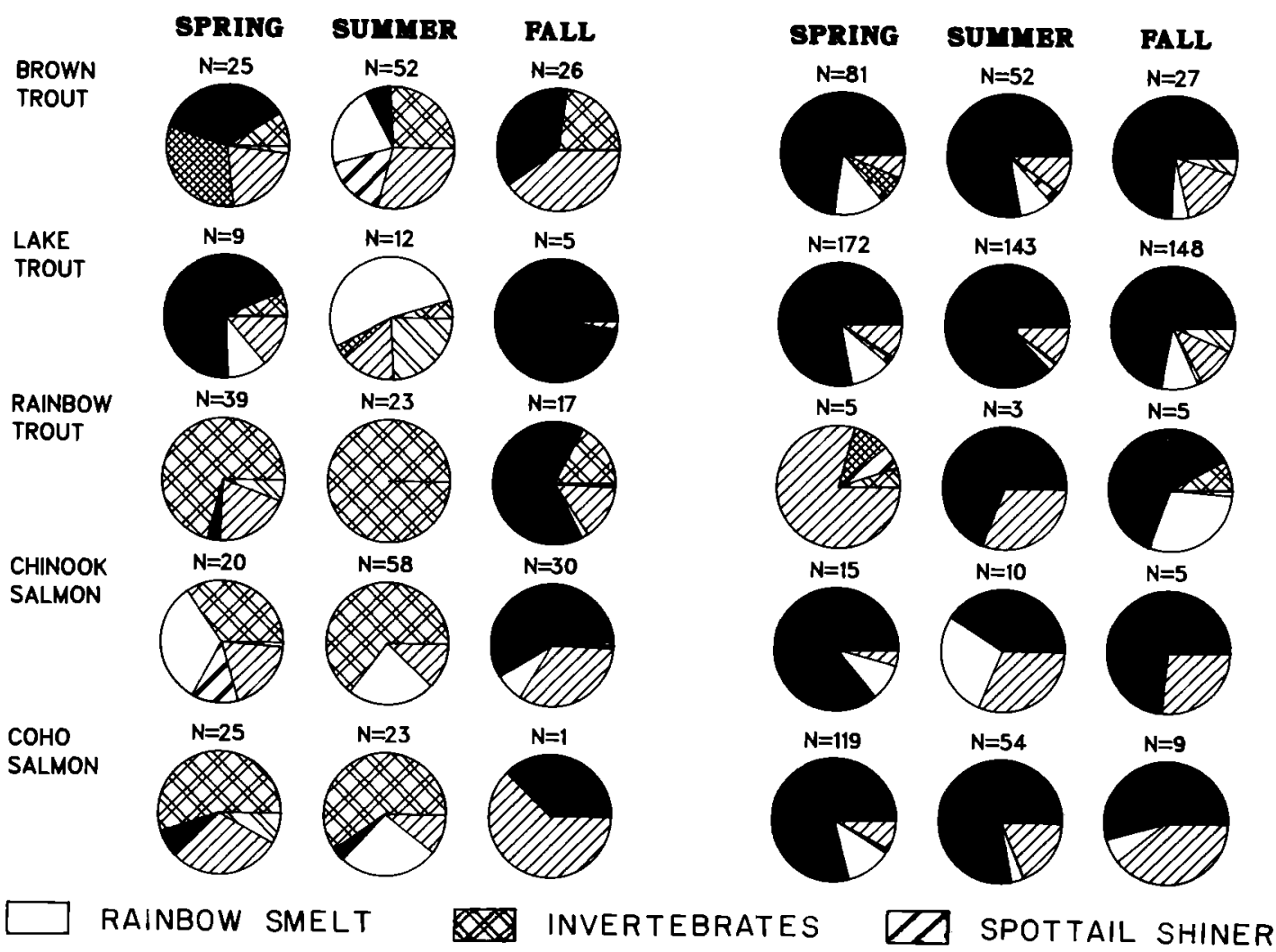

\section{ALEWIFE COTTIDS UZA UNIDENTIFIED MIS MISC.}

Figure 1.-Seasonal percent composition by weight of the diet of five species of salmonines collected from southeastern Lake Michigan. Data were pooled over 1973-1982. Left panel includes predators $30 \mathrm{~cm}$ long or less; right panel includes fish longer than $30 \mathrm{~cm}$. Miscellaneous (misc.) includes yellow perch, trout-perch Percopsis omiscomaycus, bloater, johnny darter Etheostoma nigrum, gizzard shad Dorosoma cepedianum, ninespine stickleback Pungitius pungitius, bluegill Lepomis macrochirus, fish eggs, and plants. Spottail shiner is Notropis hudsonius.

overall contributed $78 \%$ by weight to the diet (Figure 2). The remainder of the diet was predominantly rainbow smelt, particularly in spring. Infrequent occurrences of spottail shiner and sculpins in spring were also noted.

The average lengths of alewives in large coho salmon stomachs were significantly different among all seasons $(P<0.001)$; alewives eaten in summer were the longest (Table 3 ). Alewives consumed in fall were the shortest, and the average number per stomach was highest. However, the number per stomach was statistically similar among seasons $(P=0.093)$.

\section{Lake Trout}

Of 63 small lake trout examined, $70 \%$ contained food; there were no significant differences in proportion of feeding fish among seasons $(P=0.807$;
Table 1). As with larger lake trout, the total weight of prey was made up almost entirely of fish (Figure 2). Some invertebrates were eaten in spring and summer. Small lake trout were significantly longer in fall than in spring or summer.

In spring, small lake trout ate mostly alewives and some rainbow smelt (Figure 1). In fall, alewives dominated $(97 \%)$, whereas, in summer, $53 \%$ of the diet was rainbow smelt; the remainder of the diet included ninespine stickleback, troutperch, and johnny darter (Figure 1).

Among 2,132 large lake trout captured, 26\% had eaten recently. Feeding incidence was significantly lower in fall than in spring and summer (Table 1), because spawning lake trout in fall seldom fed. The index of fullness for spring was significantly higher than it was for summer or fall (Table 1). Among all salmonines, large lake trout generally 


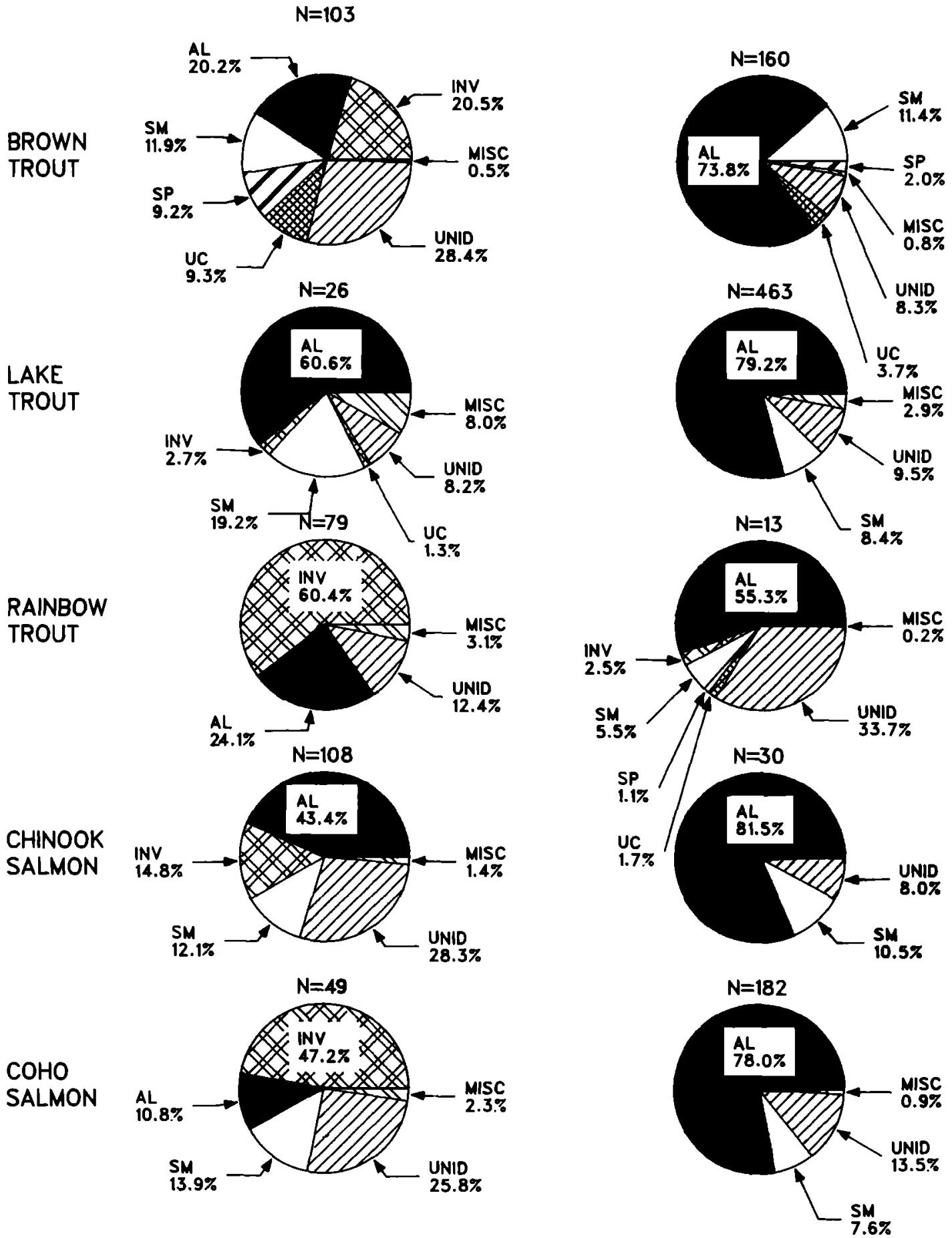

FIGURE 2.-Percent composition by weight of the diet of five species of salmonines collected from southeastern Lake Michigan. Data were pooled over 1973-1982. Left panel includes predators $30 \mathrm{~cm}$ long or less; right panel includes fish longer than $30 \mathrm{~cm}$. Misc. (miscellaneous) is defined in Figure 1 and includes all categories that composed less than $1 \%$ of the total. Prey species: $\mathrm{AL}=$ alewife; $\mathrm{SM}=$ rainbow smelt; $\mathrm{SP}=$ spottail shiner; UC $=$ sculpins (Cottus spp.); UNID = unidentified fish; INV = invertebrates. 
TABLE 2.-Seasonal values for percent frequency of occurrence of fish prey in stomachs of small and large salmonines captured in southeastern Lake Michigan, 1973-1982. Empty cells mean 0.

\begin{tabular}{|c|c|c|c|c|c|c|}
\hline \multirow[b]{2}{*}{ Sample size and fish prey } & \multicolumn{3}{|c|}{ Fish $\leq 30 \mathrm{~cm}$ total length } & \multicolumn{3}{|c|}{ Fish $>30 \mathrm{~cm}$ total length } \\
\hline & Spring & Summer & Fall & Spring & Summer & Fall \\
\hline \multicolumn{7}{|c|}{ Brown trout } \\
\hline Number of stomachs & II & 25 & 19 & 78 & 52 & 27 \\
\hline \multicolumn{7}{|l|}{ Fish prey ( $\%$ frequency) } \\
\hline Alewife & 18 & 16 & 37 & 62 & 69 & 63 \\
\hline Bluegill & 9 & & & & & \\
\hline Johnny darter & & & & 3 & & \\
\hline Rainbow smelt & & 8 & & 18 & 14 & 7 \\
\hline Spottail shiner & & 8 & & 5 & 4 & \\
\hline Unidentified cottid & 18 & & & 18 & 2 & \\
\hline Unidentified fish & 64 & 84 & 63 & 35 & 38 & 44 \\
\hline Bloater & & & & & & 4 \\
\hline \multicolumn{7}{|c|}{ Chinook salmon } \\
\hline Number of stomachs & 8 & 9 & 24 & 15 & I0 & 5 \\
\hline \multicolumn{7}{|l|}{ Fish prey ( $\%$ frequency) } \\
\hline Alewife & & & 46 & 73 & 40 & 80 \\
\hline Rainbow smelt & 38 & 33 & 8 & 33 & 30 & \\
\hline Spottail shiner & 12 & & & & & \\
\hline Trout-perch & & & 4 & & & \\
\hline Unidentified fish & 62 & 67 & 50 & 20 & 30 & 40 \\
\hline \multicolumn{7}{|c|}{ Coho salmon } \\
\hline Number of stomachs & 10 & I3 & 1 & 116 & 54 & 9 \\
\hline \multicolumn{7}{|l|}{ Fish prey ( $\%$ frequency) } \\
\hline Alewife & 20 & 8 & 100 & 65 & 78 & 67 \\
\hline Rainbow smelt & & 38 & & 17 & 9 & 11 \\
\hline Spottail shiner & & & & 2 & & \\
\hline Unidentified cottid & & & & 2 & 2 & \\
\hline Unidentified fish & 70 & 54 & 100 & 35 & 35 & 33 \\
\hline Yellow perch & 10 & & & & 2 & \\
\hline \multicolumn{7}{|c|}{ Lake trout } \\
\hline Number of stomachs & 6 & 9 & 4 & I7 1 & 143 & 146 \\
\hline \multicolumn{7}{|l|}{ Fish prey ( $\%$ frequency) } \\
\hline Alewife & 50 & & 75 & 70 & 70 & 63 \\
\hline Gizzard shad & & & & & & 4 \\
\hline Johnny darter & & 11 & & & & \\
\hline Ninespine stickleback & & 11 & & & & \\
\hline Rainbow smelt & 17 & 56 & & 18 & 5 & 8 \\
\hline Spottail shiner & & & & 4 & & 2 \\
\hline Trout-perch & & 11 & & & & \\
\hline Unidentified cottid & & 11 & & 5 & 2 & 1 \\
\hline Yellow perch & & & & 1 & 1 & 1 \\
\hline Unidentified fish & 33 & 33 & 25 & 37 & 40 & 38 \\
\hline Bloater & & & & & & 1 \\
\hline \multicolumn{7}{|c|}{ Rainbow trout } \\
\hline Number of stomachs & 9 & 0 & 8 & 4 & 3 & 2 \\
\hline \multicolumn{7}{|l|}{ Fish prey ( $\%$ frequency) } \\
\hline Alewife & 11 & & 75 & & 67 & 100 \\
\hline Rainbow smelt & & & 12 & & & 50 \\
\hline Spottail shiner & & & & 25 & & \\
\hline Unidentified cottid & & & & 25 & & \\
\hline Unidentified fish & 89 & & 38 & 50 & 33 & \\
\hline
\end{tabular}

contained the highest mean weight of food during all three seasons.

Almost exclusively, fish were eaten by large lake trout in all seasons (Figure 2). Alewives dominated the diet, particularly during summer (Figure 1).
Remaining fish eaten included rainbow smelt in spring and fall and gizzard shad in fall (Figure 1).

The average length of alewife prey was significantly shorter in fall than in spring or summer $(P<0.0001)$, but significantly higher numbers of 
TABLE 3.-Seasonal mean number and mean length $(\mathrm{mm})$ of alewives eaten by large salmonines $(>30 \mathrm{~cm})$. Values for each predator followed by the same letter are not significantly different between seasons (analyses of covariance or chi-square tests; $P<0.05$ ). Numbers of alewives measured are in parentheses. Hypothesis tests were not performed for chinook salmon and rainbow trout because of insufficient sample sizes.

\begin{tabular}{|c|c|c|c|}
\hline \multirow[b]{2}{*}{ Season } & \multirow[b]{2}{*}{$\begin{array}{l}\text { Number } \\
\text { of } \\
\text { stomachs }\end{array}$} & \multicolumn{2}{|c|}{ Alewife prey } \\
\hline & & $\begin{array}{c}\text { Mean number } \\
\text { per stomach } \pm \\
\text { SD }\end{array}$ & Mean length $\pm S D$ \\
\hline \multicolumn{4}{|c|}{ Brown trout } \\
\hline Spring & 48 & $2.6 \pm 1.9 \mathrm{zy}$ & $139 \pm 49 \mathrm{z}(120)$ \\
\hline Summer & 36 & $1.6 \pm 1.0 \mathrm{z}$ & $131 \pm 49 \mathrm{z}(49)$ \\
\hline Fall & 17 & $5.3 \pm 5.7 \mathrm{y}$ & $61 \pm 45$ y $(83)$ \\
\hline \multicolumn{4}{|c|}{ Chinook salmon } \\
\hline Spring & 11 & $2.2 \pm 1.8$ & $138 \pm 50 \quad(22)$ \\
\hline Summer & 4 & $1.0 \pm 0.0$ & $119 \pm 53$ \\
\hline Fall & 4 & $1.8 \pm 0.9$ & $92 \pm 41$ \\
\hline \multicolumn{4}{|c|}{ Coho salmon } \\
\hline Spring & 75 & $2.1 \pm 1.8 \mathrm{z}$ & $122 \pm 42 \mathrm{z}(130)$ \\
\hline Summer & 42 & $1.9 \pm 1.0 \mathrm{z}$ & $169 \pm 28$ y $(59)$ \\
\hline Fall & 6 & $4.2 \pm 4.3 \mathrm{z}$ & $51 \pm 22 \times(20)$ \\
\hline \multicolumn{4}{|c|}{ Lake trout } \\
\hline Spring & 120 & $2.1 \pm 1.5 \mathrm{z}$ & $157 \pm 36 z(233)$ \\
\hline Summer & 100 & $1.6 \pm 1.0 \mathrm{y}$ & $160 \pm 29 \mathrm{z}(140)$ \\
\hline Fall & 92 & $1.7 \pm 1.7 \mathrm{y}$ & $138 \pm 43$ y (136) \\
\hline \multicolumn{4}{|c|}{ Rainbow trout } \\
\hline Summer & 2 & $9.5 \pm 9.2$ & $104 \pm 37 \quad(19)$ \\
\hline Fall & 2 & $16.0 \pm 12.7$ & $53 \pm 6$ \\
\hline
\end{tabular}

alewives were found in stomachs in spring than in summer or fall ( $P=0.0032$; Table 3$)$. The lowest yearly weight fraction of dietary alewives occurred in 1982 (data not shown) when the alewife population was at its lowest level over the 10 -year study (Jude and Tesar 1985). We also examined our data (not shown) for changes in the size of alewives eaten between 1980-1982 (the time of the alewife population decline) and 1973-1979. We found no significant change (chi-square test) in the size (mode at $170 \mathrm{~mm}$ ) of large alewives eaten by all predators. However, during 19731979 , young-of-the-year fish $(20-60 \mathrm{~mm})$ composed about $20 \%$ of the diet numerically, but fish of this size were seldom eaten in 1980-1982 and were replaced by $80-\mathrm{mm}$ yearlings in the diet. There was a dramatic decline in young-of-the-year fish abundance starting in 1980 and concomitantly an expanded presence of yearlings in the nearshore zone in May-July; we had not observed such expansion prior to 1980 (Tesar and Jude 1985). Yearlings generally inhabit the thermocline far offshore (Brown 1972).

\section{Rainbow Trout}

Among small rainbow trout, $88 \%$ had food in their stomachs and no significant differences among seasons were found in this ratio. In spring and exclusively in summer, invertebrates dominated the diet (Figure 1). Fish were predominantly eaten in fall, although invertebrates occurred more frequently than fish then. Fish eggs and plant material composed $6 \%$ of the spring diet. Alewives $(65 \%)$ and rainbow smelt (2\%) were the only identified fish prey eaten.

Over the 10 -year study, $26 \%$ of large rainbow trout contained food; this percentage was similar among seasons (Table 1). Fish, mostly alewives, made up a large part of the diet over all seasons (55\%; Figure 2), whereas a few invertebrates (exclusively terrestrial insects) were eaten in spring and fall (5-8\%; Figure 1).

\section{Totals by Species}

When data on fish consumed by all salmonines were pooled for each predator by small $(\leq 30 \mathrm{~cm})$ and large $(>30 \mathrm{~cm})$ size groups (Figure 2), the dominance of alewives in the diet was shown clearly. For small salmonines, alewives made up from 11 to $61 \%$ by weight of the diet (Figure 2). Exclusive of unidentified fish (8-28\%), rainbow smelt was the second- or third-most important component of the fish diet of all predators except rainbow trout. Diets of large lake trout, coho salmon, and chinook salmon all were about $80 \%$ alewife by weight. Brown trout and rainbow trout ate lesser amounts. Unidentified fish or rainbow smelt were next in importance for all large predators. Brown trout $(6 \%)$ and lake trout and rainbow trout $(3 \%)$ had the greatest proportions of the more uncommonly eaten species, such as slimy sculpin Cottus cognatus, spottail shiner, gizzard shad, bloater, yellow perch, and johnny darter. Sculpins made up almost $4 \%$ of the diet of brown trout and $2 \%$ of the diet of rainbow trout. Chinook and coho salmon ate alewives and rainbow smelt almost exclusively; only $0.8 \%$ of the coho salmon's diet was other fish species.

Average number of rainbow smelt eaten by all large predators combined was similar among seasons (mean, 1.7; $N=107$; Kruskal-Wallis test, $P=0.67$ ). Average length of rainbow smelt preyed upon by all large predators combined was significantly greater in spring ( $144 \mathrm{~mm} ; N=103)$ than in summer ( $118 \mathrm{~mm} ; N=28)$ or fall $(96 \mathrm{~mm} ; N=$ 34; analysis of covariance, $P=0.002$ ). Examination of plots (not shown) of length of alewife prey 
TABLE 4. - Regression equations relating predator length $(\mathrm{mm})$ to prey length. YAL and YSM $=$ length of alewife and rainbow smelt prey, respectively; $X=$ length of one of the five salmonine predators studied, \pm SE. Asterisks denote $P \leq 0.05^{*}$ or $P \leq 0.001^{* *}$.

\begin{tabular}{|c|c|c|c|}
\hline Predator & Regression equation & $\overline{r^{2}}$ & $N$ \\
\hline Brown trout & $\begin{aligned} \mathrm{YAL} & =4.34 \pm 18.0+0.257 \pm 0.0365 X \\
\mathrm{YSM} & =40.3 \pm 33.1+0.213 \pm 0.0689 X\end{aligned}$ & $\begin{array}{l}0.340^{* *} \\
0.314^{*}\end{array}$ & $\begin{array}{l}98 \\
23\end{array}$ \\
\hline Chinook salmon & $\begin{aligned} \text { YAL } & =7.96 \pm 14.7+0.213 \pm 0.0286 X \\
Y S M & =18.6 \pm 10.5+0.206 \pm 0.0290 X\end{aligned}$ & $\begin{array}{l}0.716^{* *} \\
0.807^{* *}\end{array}$ & $\begin{array}{l}24 \\
14\end{array}$ \\
\hline Coho salmon ${ }^{a}$ & YAL $=-49.6 \pm 30.4+0.370 \pm 0.0576 X$ & $0.314^{* *}$ & 92 \\
\hline Lake trout & $\begin{array}{l}\text { YAL }=75.5 \pm 12.9+0.125 \pm 0.0194 X \\
Y S M=50.3 \pm 20.4+0.158 \pm 0.0332 X\end{array}$ & $\begin{array}{l}0.128^{* *} \\
0.312^{* *}\end{array}$ & $\begin{array}{r}284 \\
52\end{array}$ \\
\hline Rainbow trout ${ }^{\mathrm{a}}$ & $\mathrm{YAL}=18.34 \pm 25.2+0.153 \pm 0.0537 X$ & $0.504^{*}$ & 10 \\
\hline
\end{tabular}

a No significant relationship was found for rainbow smelt.

versus length of predator showed that, around a predator length of $60-70 \mathrm{~cm}$ and longer, alewife prey of maximum lengths $(200-220 \mathrm{~mm})$ were eaten. For rainbow smelt, predators $40-50 \mathrm{~cm}$ long were eating maximum-size rainbow smelt (220$245 \mathrm{~mm}$ ). The relationship between length of predator and length of alewife prey was linear and significant for all five salmonines (Table 4), whereas for rainbow smelt it was only significant for brown trout, chinook salmon, and lake trout.

Differences in percentage of stomachs containing food were examined by species and sex; no significant differences were found between sexes for large chinook salmon and brown trout. Significantly more large rainbow trout and coho salmon males than females contained food $(P=$ 0.0031 and 0.0157 , respectively), whereas, for lake trout, significantly more females contained food than males $(P<0.001)$.

\section{Selectivity and Vulnerability}

The numerical percentages of prey fish in the pooled salmonine diets and in the field catch showed that alewives were eaten in even higher proportions (78\%) than would be predicted from field catch composition ( $61 \%$; Table 5$)$, despite the near-shore bias in prey collections. A similar pattern was noted for rainbow smelt and sculpins. Spottail shiners made up $21 \%$ of the field catch, yet were only represented sparsely $(2 \%)$ in salmonine diets. Bloaters, historically part of the staple of Lake Superior lake trout diets (Dryer et al. 1965), made up an average of $1.7 \%$ of our field catch; recently their populations have increased in Lake Michigan, and in 1981 and 1982 they made up 19 and $21 \%$ of our field catches, respectively (Tesar and Jude 1985). Despite this higher abundance, salmonines seldom ate bloaters, which represented only $0.5 \%$ of their diets. Those eaten were young of the year consumed in fall 1979 and 1981 by brown and lake trout.

Alewife length frequencies from field catches and predator stomachs showed similar spring distributions over 1973-1982 (Figure 3). Peaks in both curves occurred at around $70 \mathrm{~mm}$ (yearlings) and $170 \mathrm{~mm}$. In summer, peak catches were observed for young-of-the-year $(30-40 \mathrm{~mm})$, yearling (70$80 \mathrm{~mm})$, and adult $(170 \mathrm{~mm})$ alewives. However, salmonines preyed only on the latter two groups. In fall, there was one mode in field catches at 30 $40 \mathrm{~mm}$ (young of the year) and one at 150-160 $\mathrm{mm}$ (obscured on Figure 3 because of the large catches of young of the year); fish of both sizes were preyed on heavily by salmonines. In winter, salmonines only preyed on 170-180-mm adults, despite the presence of a large group of yearlings.

Plots of field catches of rainbow smelt and those preyed on by salmonines in spring (Figure 4) both revealed peaks in abundance at $60 \mathrm{~mm}$ (young of the year) and 140-150 $\mathrm{mm}$, but the predators were

TABle 5.-Percent composition (by number) of those identified fish eaten by salmonine predators and of fish collected in southeastern Lake Michigan during monthly sampling, 1973-1982.

\begin{tabular}{lcc}
\hline \multicolumn{1}{c}{ Species } & $\begin{array}{c}\text { Eaten by } \\
\text { predators } \\
(N=1,656)\end{array}$ & $\begin{array}{c}\text { Field catch } \\
(N=1,129,606)\end{array}$ \\
\hline Alewife & 78.5 & 61.2 \\
Spottail shiner & 1.8 & 20.7 \\
Yellow perch & 0.4 & 7.2 \\
Rainbow smelt & 14.3 & 6.8 \\
Trout-perch & 0.2 & 1.9 \\
Bloater & 0.5 & 1.7 \\
Johnny darter & 0.4 & 0.2 \\
Gizzard shad & 0.9 & 0.1 \\
Cottus spp. ${ }^{a}$ & 2.9 & 0.1 \\
Ninespine stickleback & 0.1 & $<0.1$ \\
Bluegill & 0.1 & $<0.1$ \\
\hline
\end{tabular}

a Inciudes slimy and mottled sculpins ( $C$, bairdi). 


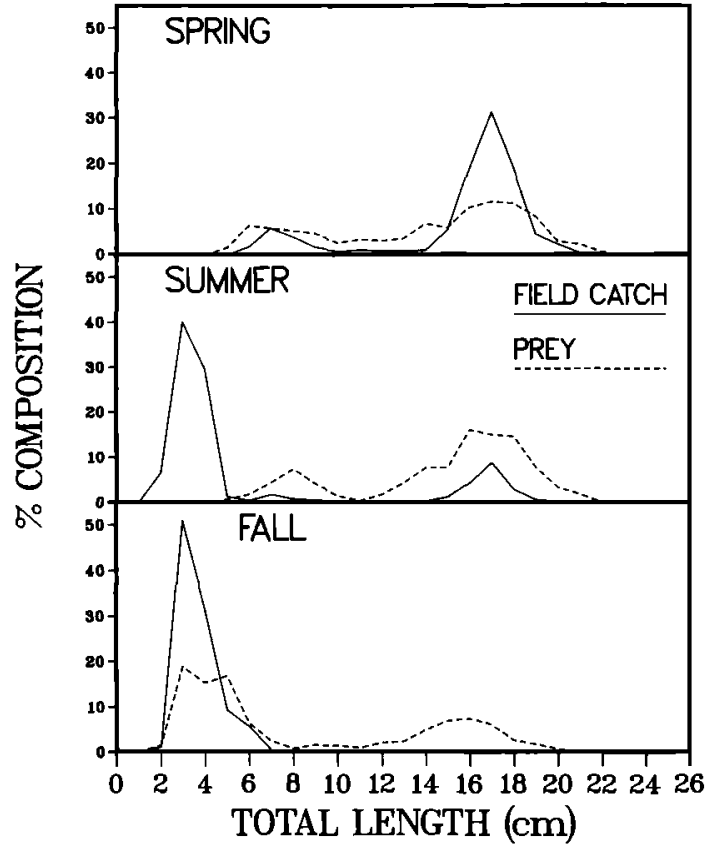

Figure 3.-Length-frequency distributions ( $\%$ of total number) for alewives collected during field surveys and for those eaten by five species of salmonines during spring, summer, and fall in southeastern Lake Michigan. Data were pooled over 1973-1982. $N=691,808$ for field catches and 1,128 for number of alewives eaten.

selective for the larger prey. This pattern was also found for summer and fall comparisons, but selectivity was not as consistent or pronounced.

\section{Discussion}

The near-shore zone is an important nursery area for juvenile salmonines, except for lake trout, which are known generally to inhabit water deeper than adults do (Martin 1951). We found that the diet of juvenile lake trout was over $60 \%$ alewife and $19 \%$ rainbow smelt by weight. In Lake Michigan, Eck and Wells (1986) found that age-1 and -2 lake trout ate young-of-the-year alewives in December and slimy sculpin in March 1982. Juvenile lake trout in Lake Ontario ate mainly slimy sculpins and, secondarily, alewives and rainbow smelt (Elrod 1983). Juveniles of other salmonine species in our study were often collected in relatively warm $\left(>20^{\circ} \mathrm{C}\right)$ beach-zone waters and were usually feeding on terrestrial insects concentrated on the surface. English (1983) and Kwain (1983) found that juvenile rainbow trout and chinook salmon ate floating insect prey. The near-shore zone provided these young salmonines with food and, perhaps, a warm-water refugium from larger predators oc-

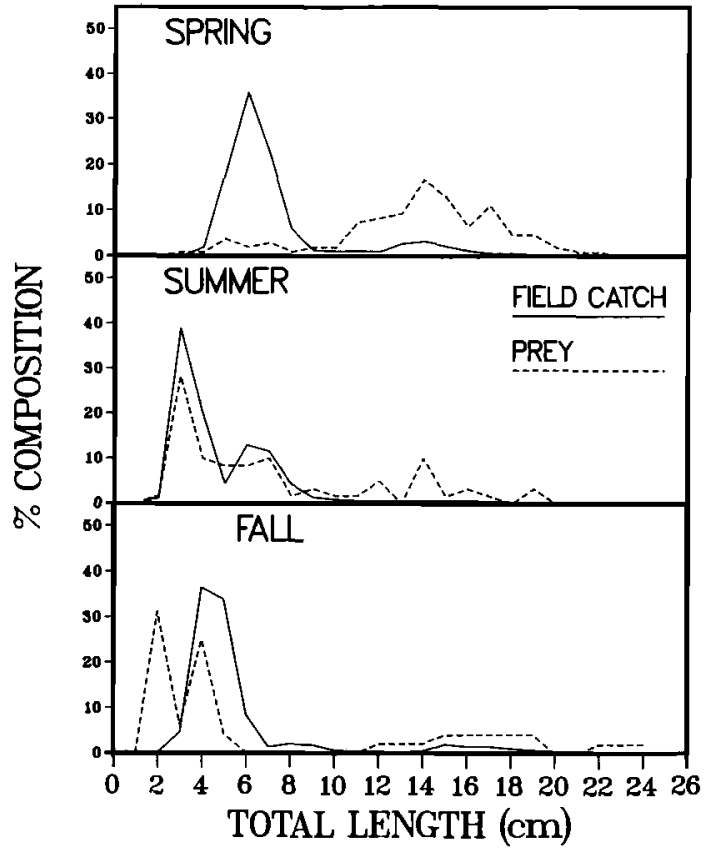

FiguRE 4.-Length-frequency distributions (\% of total number) for rainbow smelt collected during field surveys and for those eaten by five species of salmonines during spring, summer, and fall in southeastern Lake Michigan. Data were pooled over 1973-1982. $N=77,204$ for field catches and 215 for number of rainbow smelt eaten.

cupying preferred colder temperatures offshore, as was found by Engel and Magnuson (1976).

Ware $(1971,1972)$, in discussing the risk of prey to a piscine predator, cited handling time, prey exposure, food size, hunger, and previous experience as factors affecting which prey are eaten. For most prey species in Lake Michigan, we felt exposure and predator experience were most important. Spottail shiners were the second-most abundant fish collected in the study area (Jude and Tesar 1985), yet few were eaten. They are generally demersal fish, residing within the 9 -m contour where presumably waters are so warm that most predators were excluded. This pattern was also noted by Martin (1951) for Algonquin Park lake trout, which had to eat zooplankton during summer stratification because most prey fish were residing inshore and above the thermocline. Slimy sculpin in our study were eaten in spring; they appear to be more susceptible to predation during their migrations closer to shore for spawning and nest guarding activities. They were the third-most important prey eaten and made up $32 \%$ of the diets of small brown trout in spring. They were also fed on extensively in Lake Michigan during 
March 1982, when lake trout apparently overlapped their distribution, whereas alewives, which were farther offshore, were not eaten to any substantial degree (Eck and Wells 1986). Christie et al. (1987) maintained that slimy sculpin were the preferred prey of Lake Ontario lake trout, and Van Oosten and Deason (1938) showed that Cottidae were important food for southern Lake Michigan lake trout before their populations collapsed.

Only $0.4 \%$ (six fish) of all fish eaten by salmonines were yellow perch, a reflection of their reduced abundance in the 1970 s. Recently, more are being consumed by salmonines, particularly during times of thermal overlap between predator and prey during spring, during upwellings, and especially during fall (Hagar 1984; N. Kevern, Michigan State University, personal communication), the time of maximum energetic demands on predators (Edsall et al. 1974; Stewart et al. 1981). Martin (1951) found that considerable spatial overlap between lake trout and yellow perch occurred during stratification of an Algonquin Park lake where yellow perch, especially young of the year, extended out to $12^{\circ} \mathrm{C}$ water and were fed upon heavily by lake trout.

Bloaters have increased dramatically in abundance, starting in 1978 (Jude and Tesar 1985). Only a few were eaten during this study, in contrast to pre-sea lamprey Petromyzon marinus days (Van Oosten and Deason 1938; Dryer et al. 1965), when much of the lake trout diet was composed of coregonines, including bloaters. Despite their extremely disparate population abundances, almost twice as many gizzard shad as bloaters were eaten by salmonines during our study. In more recent studies, bloaters have made up increasing proportions of salmonine diets, especially in fall (J. Janssen, Loyola University, Chicago, personal communication), but still not to the degree expected. Bloaters may have taken up a more benthic existence in response to competition from alewives (Crowder and Crawford 1984), which would place them out of the pelagic zone where most salmon search for food. In addition, alewives may still be buffering bloaters. Formation of a prey search image, as Ware (1971) suggested occurred for rainbow trout, may be delayed, perhaps explaining why salmonines are still preying heavily on alewives despite the increased abundance of bloaters.

Alewives were the preferred prey of all five salmonines collected, making up $55-82 \%$ by weight of the diet of large fish. The actual percentages are undoubtedly higher than we measured because another $8-34 \%$ of the diet was unidentified fish. Alewives dominated the diets of southern Lake Michigan salmonines in 1970 (McComish and Miller 1976) and of Lake Ontario salmonines in 1983-1984 (Brandt 1986); rainbow smelt were second in importance (which we also found). Stomachs of small rainbow trout had the highest proportions of invertebrates (17-100\% over all three seasons); salmonine foraging behavior work done by J. Savitz (Loyola University, Chicago, personal communication) showed that rainbow trout were the slowest of all salmonines studied, only catching prey in pelagic waters when reactive distances were small.

Alewife, a marine exotic, entered Lake Michigan in the 1940s (Miller 1957) in the almost total absence of top predators after lake trout collapsed (Smith 1968; Christie 1974) and with very little competition from the historical deepwater planktivores (the "chub complex": Smith 1964). Stocking of predators started first with lake trout in 1965 , followed by brown trout, rainbow trout, and coho and chinook salmon. For the newly stocked salmonines, alewives were abundant and easy to catch, and search images (Holling 1959; Marcotte and Browman 1986) were undoubtedly formed. These piscivores selected alewives over other prey in Lake Michigan, a pattern that Holling (1973) referred to as contagious predation. We feel the exotic alewives are more vulnerable prey than endemic species such as the bloater. Alewives have not fully adapted to fresh water, as exemplified by iodine deficiencies (Colby 1973) and by severe mortalities in spring and during cold winters (Eck and Brown 1985). In contrast, cold water is optimal habitat for salmonines. Salmon are pelagic, continuously swimming predators (Lackey 1970; Speirs 1974); thus alewife schools suspended in midwater present vulnerable targets for these fish. While scuba diving in Lake Michigan, we have observed large schools of alewives, which were suspended in the entire water column at $9 \mathrm{~m}$ and were visible from long distances as a large shimmering sheet. Behavioral work by Savitz (personal communication) showed that chinook salmon had the highest swimming speeds of salmonines tested and that pelagic alewives were easily detected and dispatched, in contrast to demersal yellow perch, which were often ignored.

Recently, alewife populations in southeastern Lake Michigan have declined dramatically (Jude and Tesar 1985). Implications of this decline could be serious for the sport fishery because of the importance of this prey in salmonine diets. Stewart 
et al. (1981) warned of the dangers of overstocking salmonine predators that could eventually outstrip the alewife prey base. Concurrent with the alewife decline, bloaters and yellow perch have increased (Jude and Tesar 1985). We examined our data for evidence that salmonines were switching (Murdoch 1969; Murdoch et al. 1975) to alternate prey species, especially to bloater, but, despite an $86 \%$ decline in alewife abundance, a 10 -fold increase in bloater abundance, and a 5 -fold increase in yellow perch abundance, no diet shift had occurred as of 1982. Apparently, alewives were still being eaten selectively (depensatory mortality), buffering bloaters from increased predation. Lake trout in Lake Opeongo switched from yellow perch, when the latter declined, to lake whitefish and lake herring Coregonus artedi (Martin 1970). In 1984, Lake Erie coho salmon switched from rainbow smelt to yellow perch when rainbow smelt declined and yellow perch formed a strong year class (A. Timmerman, Lake Erie Fisheries Assessment Unit, personal communication). Christie et al. (1987) noted that stocked lake trout in the Kingston basin of eastern Lake Ontario ate increasing amounts of alewife as rainbow smelt and slimy sculpin became less abundant. They concluded that alewife was the third choice, as lake trout preferentially ate slimy sculpin first, then rainbow smelt.

Salmonine predators fed on alewives of all sizes, but selected different sizes at different times during the year. Modes in sizes of alewives eaten during spring and summer occurred at around 80 and $170 \mathrm{~mm}$. These modes corresponded well with modes in our field catches, except that young of the year, which generally occupied the near-shore zone $(6 \mathrm{~m}$ or less) where water temperatures are highest (Jude et al. 1979), remained inaccessible to salmonine predators during summer months, except during upwellings. These data suggest that salmonines were eating prey in proportion to their abundance in the field only when preferred temperatures of predator and prey overlapped (for example, see Martin 1951; Engel and Magnuson 1976). Elrod (1983) also found that the incidence of prey fish in Lake Ontario trawl catches was similar to the occurrence of these fish in lake trout diets. Christie et al. (1987) found that lake trout in the Kingston basin, Lake Ontario, ate smaller prey on average than those trawled, but predators generally ate fish of sizes that were available to them. During fall in our study, young-of-the-year alewives were heavily preyed upon along with adults around $160 \mathrm{~mm}$. Young-of-the-year ale- wives were also heavily preyed upon by lake trout in Lake Michigan in December (Eck and Wells 1986). The predation pattern was similar for rainbow smelt, except that young of the year were fed upon during summer and fall, a reflection of this species' more offshore nursery grounds that overlap with the predators' distributions. The mean length of rainbow smelt eaten was longest in spring when the prey appeared to be more susceptible to predation during onshore spawning runs; mean prey length declined through summer and fall as more juveniles were eaten.

Plots of predator length versus prey length for both prey species showed that predators above $60-70 \mathrm{~cm}$ consumed maximum sizes of prey. Salmonine predators greater than $70 \mathrm{~cm}$ could eat much larger prey if the latter were available and susceptible. A direct relationship between predator and prey sizes was found for lake trout and their prey in Lake Opeongo (Martin 1970) and in southern Lake Michigan in 1970 (McComish and Miller 1976). In Lake Ontario, Brandt (1986) found a significant relationship for only one of five salmonine species and its alewife prey. In Lake Michigan, the only species that could fill this void would be large bloaters, rainbow smelt, and perhaps lake whitefish Coregonus clupeaformis, a species eaten by lake trout in Lake Opeongo (Martin 1970). A currently invading species, pink salmon Oncorhynchus gorbuscha (Kwain and Lawrie 1981), reaches sizes to $390 \mathrm{~mm}$ fork length; it is pelagic and mostly planktivorous. This species could provide another larger prey fish. In the mid1980 s, during the period of low alewife abundance (Jude and Tesar 1985), researchers did not observe a significant relationship between predator and prey sizes because more of the smaller alewives were eaten (Hagar 1984; Kevern, personal communication). Offshore, young of the year and yearlings inhabit warmer, more pelagic waters, whereas adults tend to be closer to the bottom (Wells 1968; Brown 1972; Brandt et al. 1980), thus making the smaller fish more vulnerable to predatory salmon residing at middepths. As further evidence, lake trout, which tend to be more demersal predators, ate the largest alewives of all predators (with one exception) during all three seasons.

The decline of alewives in Lake Michigan has cascaded through other parts of the ecosystem (Carpenter et al. 1985). Zooplankton size structure did not change inshore as yellow perch predation replaced alewife predation, but larger offshore zooplankton increased in abundance and Daphnia 
pulicaria became dominant (Evans and Jude 1986). Because these large Daphnia pulicaria are more efficient at removing particles, including phytoplankton, from the water column than was the former copepod-dominated zooplankton, dramatic increases in water clarity were observed in the early 1980s (Scavia et al. 1986). In addition, current studies (1983-1986) of salmonine diets (Hagar 1984; Janssen, personal communication; Kevern, personal communication), have documented increased diet diversity, more empty stomachs than in the early 1980 s, and a shift to a high proportion of young-of-the-year alewives rather than adults in stomachs. However, alewives still make up a higher-than-expected proportion of the diet. The lake should be able to sustain a higher biomass of young-of-the-year alewives than of older age groups, because the amount of food consumed that is converted to body biomass of young of the year $(5 \%)$ is much higher than that of adults (1.3-2.8\%) (Stewart and Binkowski 1986). Christie et al. (1987) also alluded to this for alewives in the Kingston Basin, Lake Ontario; these authors suggested that there may have been changes in secondary production caused by size-selective predation on zooplankton that enhanced production of lower trophic levels, thus favoring growth of alewives.

Fish managers may now be in a unique position to forge changes in prey populations that will benefit the Lake Michigan fish community and the sport and commercial fisheries, and that will provide direction and forewarning elsewhere. Managers must increasingly manage ecosystems with uncoupled predators and prey, so the history of changes in Lake Michigan will provide a suite of possible scenarios that may occur. The alewife population has fluctuated wildly since entering Lake Michigan, acting like most exotic species that attain dominance in new ecosystems, first increasing, then crashing, then maintaining some equilibrium (Smith 1970; Brown 1972). Christie et al. (1987) considered the alewife to be integrated into the Lake Ontario system, because it has been an important part of the lake trout diet since the 1920 s. O'Gorman and Schneider (1986) maintained that alewives there are very resilient and will be able to withstand considerable predation pressure. Still, alewife populations are difficult to manage and present substantial risk to fish managers who must depend on this prey base for the extensive salmonine stocking programs now in place in the Great Lakes. Managers now have the opportunity to continue this predatory pressure and force the
Lake Michigan fish community toward one that has less dependence on exotic, variably recruited prey species to one that has historically abundant and endemic species, such as yellow perch, bloater, deepwater sculpin Myoxocephalus thompsoni, and, more recently, emerald shiner Notropis atherinoides (Great Lakes Research Division, University of Michigan, unpublished data), provided that these regain numerical abundance. These populations are inherently more stable because they evolved in Lake Michigan, they should be somewhat easier to manage, and they can act as important commercial, sport, and prey fish. There should be a reduction in transfer of toxic substances to upper levels in the food chain if species such as yellow perch make up a higher proportion of salmonine diets. Alewives are very inefficient in food conversion and should concentrate more toxic substances than do other species which have higher food conversion efficiencies (Flath and Diana 1985; Stewart and Binkowski 1986).

Eventually, salmonines may switch to the now more abundant bloater, which should be closely monitored. Bloaters are more important commercially than alewives, so some conflict may develop in allocation of the bloater resource. Those salmonines with a more diverse diet should be able to take advantage of the now more abundant non-alewife prey. These include brown trout, whose overall non-alewife prey made up $18 \%$ by weight of the diet of large fish in our study, and lake trout $(11 \%)$. Both species appear to be more demersal predators than the salmon, and will encounter more of the now abundant, underutilized prey species, such as yellow perch, trout-perch, and, to a lesser degree, bloater. There is a large population of spottail shiners in near-shore southeastern Lake Michigan that was seldom preyed upon by salmonines. Yellow perch are so abundant now that their growth has been depressed through density-dependent effects (Wells 1985; Great Lakes Research Division, unpublished data). Walleye might be a species to introduce to utilize this currently untapped resource. The largely unexploited deepwater sculpin also has greater potential to be consumed by lake trout, because deepwater sculpins were important prey for lake trout before that predator became extinct in Lake Michigan (Dryer et al. 1965).

\section{Acknowledgments}

We thank the many members of the Great Lakes Research Division's Fishery Laboratory, who, over the 10 years of the study, helped with data collec- 
tion. Particular thanks go to senior members D. Bimber, D. Einhouse, M. Enk, J. Dorr III, G. Godun, C. Madenjian, P. Mansfield, P. Rago, H. Tin, N. Thurber, and J. Tomlinson; L. Flath did some early processing of data. Text processing was handled by J. Huhn, M. Sweeney, and B. McClellan. We thank G. Stoermer, C. Schelske, N. Ringler, D. Stewart, and two anonymous reviewers for constructive comments. The study was funded by the American Electric Power Service Corporation, Indiana and Michigan Power Company, to whom we are indebted. This is Great Lakes Research Division Contribution 468.

\section{References}

Brandt, S. 1986. Food of trout and salmon in Lake Ontario. Journal of Great Lakes Research 12:200 205.

Brandt, S., J. Magnuson, and L. Crowder. 1980. Thermal habitat partitioning by fishes in Lake Michigan. Canadian Journal of Fisheries and Aquatic Sciences 37:1557-1564.

Brown, E. H., Jr. 1972. Population biology of alewives, Alosa pseudoharengus, in Lake Michigan, 19491970. Journal of the Fisheries Research Board of Canada 29:477-500.

Carpenter, S., F. Kitchell, and J. Hodgson. 1985. Cascading trophic interactions and lake productivityfish predation and herbivory can regulate lake ecosystems. BioScience 35:634-639.

Christie, W. J. 1974. Changes in the fish species composition of the Great Lakes. Journal of the Fisheries Research Board of Canada 31:827-854.

Christie, W. J., K. A. Scott, P. G. Sly, and R. H. Strus. 1987. Recent changes in the aquatic food web of eastern Lake Ontario. Canadian Journal of Fisheries and Aquatic Sciences 44 (Supplement 2):37-52.

Colby, P. J. 1973. Response of the alewives, Alosa pseudoharengus, to environmental change. Pages 163-198 in W. Chavin, editor. Responses of fish to environmental changes. Thomas, Springfield, Illinois.

Crowder, L., and H. Crawford. 1984. Ecological shifts in resource use by bloaters in Lake Michigan. Transactions of the American Fisheries Society 113 : 694-700.

Dryer, W. R., L. F. Erkkila, and C. L. Tetzloff. 1965. Food of lake trout in Lake Superior. Transactions of the American Fisheries Society 94:169-176.

Eck, G. W., and E. H. Brown, Jr. 1985. Lake Michigan's capacity to support lake trout (Salvelinus namaycush) and other salmonines: an estimate based on the status of prey populations in the $1970 \mathrm{~s}$. Canadian Journal of Fisheries and Aquatic Sciences 42:449-454.

Eck, G. W., and L. Wells. 1986. Depth distribution, diet, and overwinter growth of lake trout (Salvelinus namaycush) in southeastern Lake Michigan sampled in December 1981 and March 1982. Journal of Great Lakes Research 12:263-269.
Edsall, T., E. Brown, Jr., T. Yocum, and R. Wolcott. 1974. Utilization of alewives by coho salmon in Lake Michigan. U.S. Fish and Wildlife Service, Great Lakes Fishery Laboratory, Administrative Report, Ann Arbor, Michigan.

Elrod, J. H. 1983. Seasonal food of juvenile lake trout in U.S. waters of Lake Ontario. Journal of Great Lakes Research 9:396-402.

Engel, S., and J. J. Magnuson. 1976. Vertical and horizontal distributions of coho salmon (Oncorhynchus kisutch), yellow perch (Perca flavescens), and cisco (Coregonus artedii) in Pallette Lake, Wisconsin. Journal of the Fisheries Research Board of Canada 33:2710-2715.

English, K. 1983. Predator-prey relationships for juvenile chinook salmon, Oncorhynchus tshawytscha, feeding on zooplankton in "in situ" enclosures. Canadian Journal of Fisheries and Aquatic Sciences 40:287-297.

Evans, M., and D. J. Jude. 1986. Recent shifts in Daphnia community structure in southeastern Lake Michigan: a comparison of the inshore and offshore. Limnology and Oceanography 31:56-67.

Flath, L. E., and J. S. Diana. 1985. Seasonal energy dynamics of the alewife in southeastern Lake Michigan. Transactions of the American Fisheries Society 114:328-337.

Hagar, J. 1984. Diets of Lake Michigan salmonids: an assessment of the dynamics of predator-prey interactions. Master's thesis. University of Wisconsin, Madison.

Holling, C. S. 1959. Some characteristics of simple types of predation and parasitism. Canadian Entomologist 91:385-398.

Holling, C. S. 1973. Resilience and stability of ecological systems. Annual Review of Ecology and Systematics $4: 1-23$.

Hyslop, E. J. 1980. Stomach content analysis-a review of methods and their application. Journal of Fish Biology 17:411-429.

Jude, D. J., and six coauthors. 1979. Inshore Lake Michigan fish populations near the D. C. Cook Nuclear Power Plant during preoperational years1973-1974. University of Michigan, Great Lakes Research Division, Special Report 71, Ann Arbor.

Jude, D. J., and F. J. Tesar. 1985. Recent changes in the inshore forage fish of Lake Michigan. Canadian Journal of Fisheries and Aquatic Sciences 42:11 154 1157.

Kwain, W. 1983. Downstream migration, population size, and feeding of juvenile rainbow trout. Journal of Great Lakes Research 9:52-59.

Kwain, W., and A. H. Lawrie. 1981. Pink salmon in the Great Lakes. Fisheries (Bethesda) 6(2):2-6.

Lackey, R. T. 1970. Seasonal distribution of Atlantic salmon, brook trout, alewives, and American smelt in a small lake. Journal of the Fisheries Research Board of Canada 27:1656-1661.

Marcotte, B., and H. Browman. 1986. Foraging behavior in fishes: perspectives on variance. Environmental Biology of Fishes 16:25-33.

Martin, N. V. 1951. A study of the lake trout Salveli- 
nus namaycush in two Algonquin Park, Ontario, lakes. Transactions of the American Fisheries Society $81: 111-137$.

Martin, N. V. 1970. Long-term effects of diet on the biology of the lake trout and the fishery in Lake Opeongo, Ontario. Journal of the Fisheries Research Board of Canada 27:125-146.

McComish, T., and W. Miller. 1976. Notes on the biology of the lake trout and other Salmonidae in Indiana waters of Lake Michigan. Proceedings of the Indiana Academy of Science 85:161-169.

Miller, R. R. 1957. Origin and dispersal of the alewife, Alosa pseudoharengus, and the gizzard shad, Dorosoma cepedianum, in the Great Lakes. Transactions of the American Fisheries Society 86:97-111.

Murdoch, W. W. 1969. Switching in general predators: experiments on predator specificity and stability of prey populations. Ecological Monographs 39:335354.

Murdoch, W. W., S. Avery, and M. Smyth. 1975. Switching in predatory fish. Ecology 56:1094-1105.

O'Gorman, R., and C. Schneider. 1986. Dynamics of alewives in Lake Ontario following a mass mortality. Transactions of the American Fisheries Society 115:1-14.

Scavia, D., G. Fahnenstiel, M. Evans, D. Jude, and J. Lehman. 1986. Influence of salmonine predation and weather on long-term water quality trends in Lake Michigan. Canadian Journal of Fisheries and Aquatic Sciences 43:435-443.

Smith, S. H. 1964. Status of the deepwater cisco populations of Lake Michigan. Transactions of the American Fisheries Society 93:155-163.

Smith, S. H. 1968. Species succession and fishery exploitation in the Great Lakes. Journal of the Fisheries Research Board of Canada 25:667-693.

Smith, S. H. 1970. Species interactions of the alewife in the Great Lakes. Transactions of the American Fisheries Society 99:754-765.

Speirs, G. 1974. Food habits of landlocked salmon and brook trout in a Maine lake after introduction of landlocked alewives. Transactions of the American Fisheries Society 103:396-399.

Stewart, D. J., and F. P. Binkowski. 1986. Dynamics of consumption and food conversion in Lake Michigan alewives: an energetics-modeling synthesis. Transactions of the American Fisheries Society 115 : 643-661.

Stewart, D. J., J. F. Kitchell, and L. B. Crowder. 1981. Prey fishes and their salmonid predators in Lake Michigan. Transactions of the American Fisheries Society $110: 751-763$.

Tesar, F. J., and D. J. Jude. 1985. Adult and juvenile fish populations of inshore southeastern Lake Michigan near the Cook nuclear power plant, 1973-82. University of Michigan, Great Lakes Research Division, Special Report 106, Ann Arbor.

Van Oosten, J., and H. Deason. 1938. The food of the lake trout (Cristivomer namaycush namaycush) and of the lawyer (Lota maculosa) of Lake Michigan. Transactions of the American Fisheries Society 67: 155-177.

Ware, D. 1971. Predation by rainbow trout: the effect of experience. Journal of the Fisheries Research Board of Canada 28:1847-1852.

Ware, D. 1972. Predation by rainbow trout: the influence of hunger, prey density, and prey size. Journal of the Fisheries Research Board of Canada 29:11931201.

Wells, L. 1968. Seasonal depth distribution of fish in southeastern Lake Michigan. U.S. Fish and Wildlife Service Fishery Bulletin 67:1-15.

Wells, L. 1985. Changes in Lake Michigan's prey fish populations with increasing salmonid abundance, 1962 to 1984. Pages 13-25 in R. L. Eshenroder, editor. Great Lakes Fishery Commission Special Publication 85-3, Ann Arbor, Michigan.

Received March 22, 1986

Accepted December 21, 1987 